\title{
Artur Kamczycki
}

(Gniezno)

\section{UNHEIMLICH: STRUKTURY PUSTKI W BERLIŃSKIM MUZEUM LIBESKINDA}

DOI 10.14746/SEG.2014.10.15

\section{Abstract}

The paper focuses on the analysis of architectural structure of the Jewish Museum in Berlin, designed in 1988 by Daniel Libeskind. The starting point here is the building's internal Void, existing as a closed, separated section of the edifice. The context for the analysis is derived from the Freudian notion of unheimlich (uncanny), which was suggested to Libeskind by Jacques Derrida.

\section{Key words}

Libeskind's Jewish Museum in Berlin, theory of architecture, Unheimlich, Holocaust 
W 1988 r. rząd Republiki Federalnej Niemiec zorganizował konkurs na realizację muzeum 2000 lat niemiecko-żydowskiej historii, mającego odnosić się także do Holokaustu. Budynek przewidziany był jako tzw. oddział (niem. Abteilung) istniejącego już Muzeum Miasta Berlina, znajdującego się w barokowym pałacu (Kollegienhaus) z czasów Fryderyka Wilhelma I (1713-1740) przy Lindenstrasse na Kreuzbergu' ${ }^{1}$. To ważne politycznie muzeum federalne miało być otwarte $\mathrm{w} 330$. rocznicę powstania żydowskiej gminy w tym mieście ${ }^{2}$. W konkursie wzięło udział stu sześćdziesięciu architektów z całego świata, którzy otrzymali względną dowolność konceptualną na ów projekt. Pomysł Daniela Libeskinda został uznany za najciekawszy i przedłożony do realizacji³. Dziesięć lat później po raz pierwszy otwarto budowlę dla publiczności. Sale były jeszcze puste, ale w ciągu roku tę nową konstrukcję zwiedziło 350 tys. ludzi.

Barokowy gmach Kollegienhaus - połączony z nowym skrzydłem tylko podziemnym przejściem - jest murowaną, dwukondygnacyjną, dwuskrzydłową budowlą z dziedzińcem, zwieńczoną dachem mansardowym ${ }^{4}$ [il. 1, 2]. Natomiast tzw. dobudówka (Abteilung) wzniesiona została na „zygzakowatym” planie przypominającym błyskawicę (lub pełzającego węża albo zdruzgotaną Gwiazdę Dawida). Forma zewnętrzna budynku jawi się jako zestawiona z kubicznych brył, nieregularna, kanciasta, blaszana konstrukcja o płaskim dachu. Ta dynamiczna, ekspresyjna budowla składa się z czterech kondygnacji, na których zamiast neutralnych sal muzealnych zaprojektowano nieregularne, ukośne przestrzenie, a w ścianach rozlokowano wąskie, podłużne formy okien. Rozciągnięty, zygzakowaty budynek — w swej strukturze „wewnętrznej” — został przecięty prostą,

${ }^{1}$ Zob. np.: R. Bothe, V. Bendt, Realisierung Wettbewerg: Eweiterung Berlin Museum mit Abteilung Jüdisches Museum, Berlin 1990; R. Bothe, Das Berlin Museum und sein Erweiterungsbau/The Jewish Museum and ist Extention, [w:] K. Feireiss (red.), Daniel Libeskind: Erweiterung des Berlin Museums mit Abteilung Jüdisches Museum/Daniel Libeskind: Extension to the Berlin Museum with Jewish Museum Department (katalog niem./ang.), Berlin 1992, s. 33-52 (dalej cytowane w wersji angielskiej jako: Extension to).

${ }^{2}$ Stories of an Exhibition. Two Millenia of German Jewish History (autor zbiorowy, wprowadzenie: Julian Nida-Rümelin), Stiftung Jüdisches Museum Berlin 2005. Zob. też: R. Gay, The Jews of Germany. A Historical Portrait, New Haven-London 1992; N.T. Gidal, Jews in Germany. From Roman Times to the Weimar Republic, Cologne 1998; M. Brenner, The Renaissance of Jewish Culture in Weimar Germany, New Haven 1996.

${ }^{3}$ Zob. np.: D. Libeskind, Przełom: przygody w życiu i architekturze, tłum. M. Zawadka, Warszawa 2004, s. 63-79.

${ }^{4}$ Wnętrza tego pałacu architekt zaadaptował na pomieszczenia z kasami biletowymi, szatnię, księgarnię, salę konferencyjną i restaurację. 


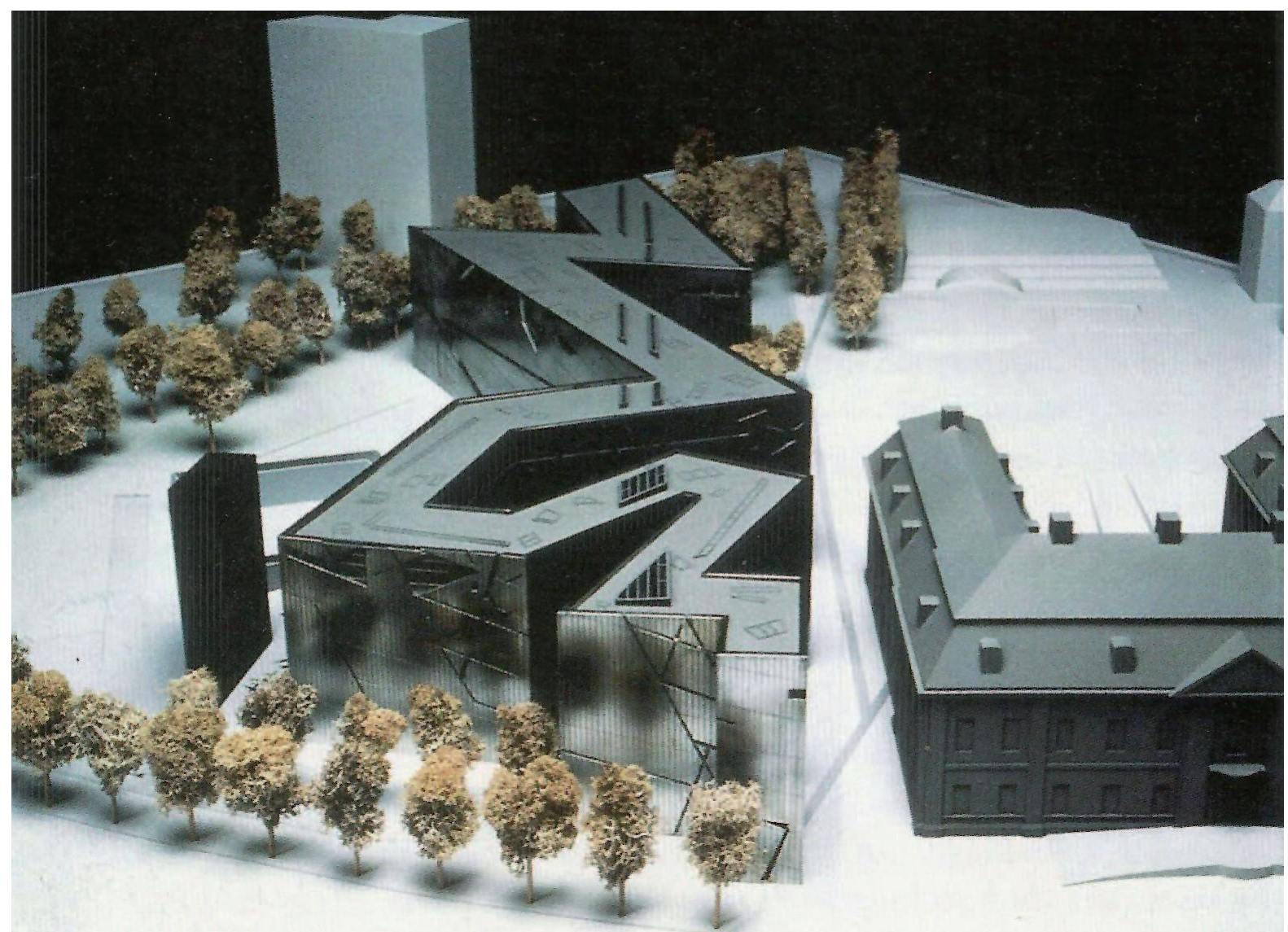

Il. 1. Model projektu (ujęcie negatywowe). Źródło: J.E. Young, At Memory’s Edge. After-Image of the Holocaust in Contemporary Art and Architecture, New Haven-London 2000, s. 168

szeroką na 4 i pół metra, wysoką na 27 i długą na 150 metrów, lecz przerywaną wzdłuż głównej osi budowli linią, tworzącą pustą przestrzeń (lub puste przestrzenie) sięgającą od przyziemia aż do dachu i szczelnie oddzieloną od pozostałych części konstrukcji ${ }^{5}$ [il. 3]. Są to betonowe, gołe powierzchnie wewnątrz nieznacznie rozjaśnione naturalnym światłem przez małe okna $w$ dachu ${ }^{6}$ [il. 4]. Jak pisze Libeskind, „Nie jest to żadne atrium, nic, co można by «zwiedzić», przejść, nie jest czymś, co można by w całości zobaczyć. Biegnie przez całą strukturę i przecina budynek na części”

${ }^{5}$ B. Schneider, D. Libeskind, Jewish Museum of Berlin. Between the Lines, Munich 1999 (wyd. 4: D. Libeskind, Jewish Museum Berlin, Munich 2005), s. 48-58. Zob. też: E. Dorner, D. Libeskind, Jüdisches Museum, Berlin 1999.

${ }^{6}$ Wymiary tej przestrzeni podyktowane są wielkością całego budynku, tj. całkowitą wysokością, długością oraz - odpowiednio do układu - szerokością.

${ }^{7}$ [It is not an atrium; it is not something you can walk through; it is not something that can ever be seen in its entirety. It runs through all the collections and divides the building]. D. Libes- 


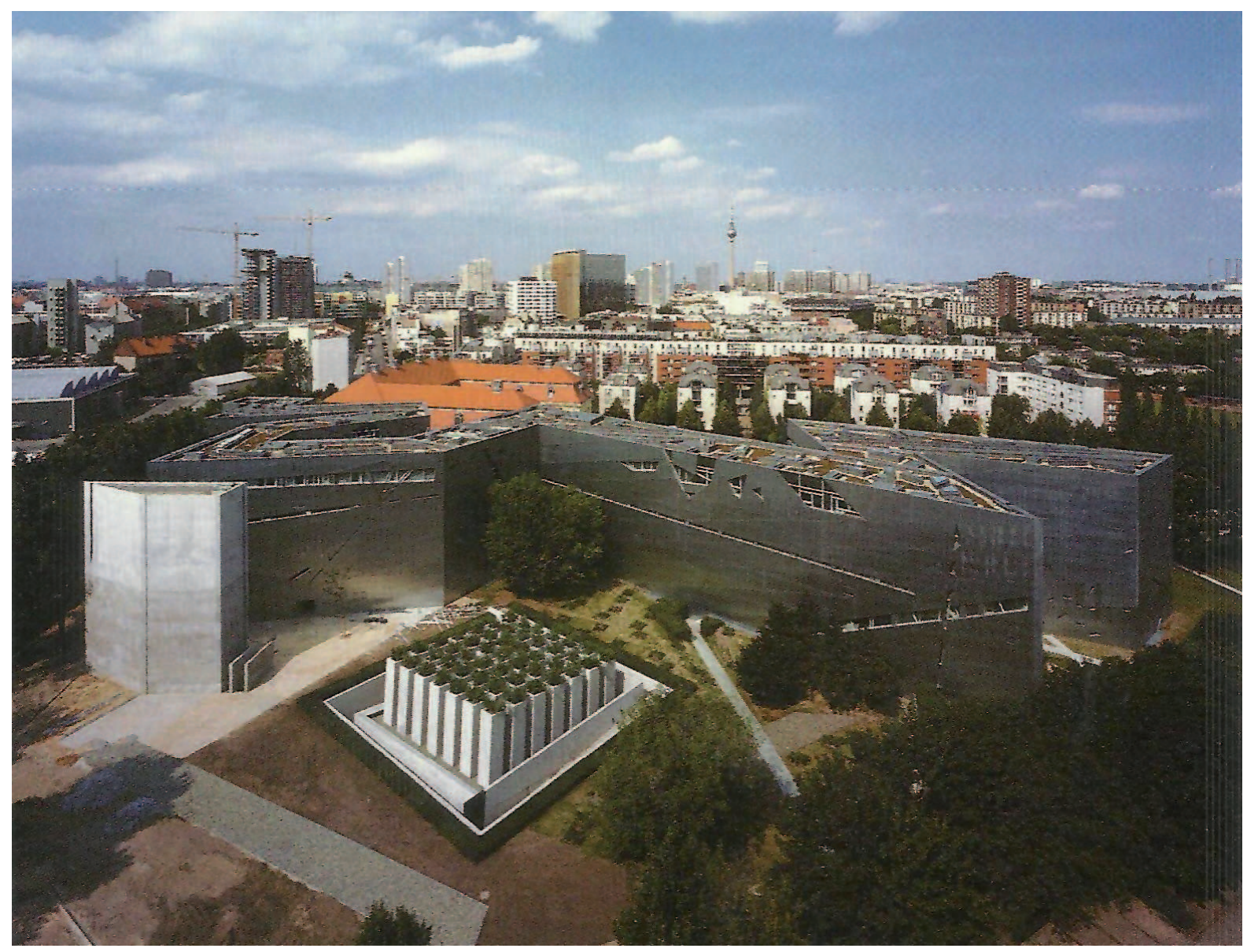

Il. 2. Widok ogólny. Źródło: J.E. Young, At Memory’s Edge, s. 169

Warto zauważyć, że dla samego terminu Pustki, inkorporowanej w strukturę projektu, Libeskind często w swoich tekstach rezerwuje szczególne znaczenia, zapisując je w cudzysłowie, kursywą lub z dużej litery (jako „Void”)

W pierwotnym założeniu struktura ta miała być w całości zamkniętą, niedostępną, odseparowaną częścią budowli. Jednak w konfrontacji z komisją konkursową, która ze względu na powiększającą się kolekcję nie widziała celu w pozostawieniu aż 1/3 kubatury budynku dla niej samej, ostateczny rezultat jest wynikiem pewnego kompromisu. Jak mówi sam Libeskind: jego zadaniem

kind, Trauma, [w:] S. Horstein, F. Jacobowitz (red.), Image and Remembrance. Representation and the Holocaust, Bloomington-Indianapolis 2003, s. 57 (43-58) (tłum. własne).

${ }^{8}$ Zob. też: J.E. Young, Daniel Libeskind's New Jewish Architecture, [w:] C. Wolf (red.), Daniel Libeskind and the Contemporary Jewish Museum: New Jewish Architecture from Berlin to San Francisco, San Francisco 2008, s. 50 (45-61). 


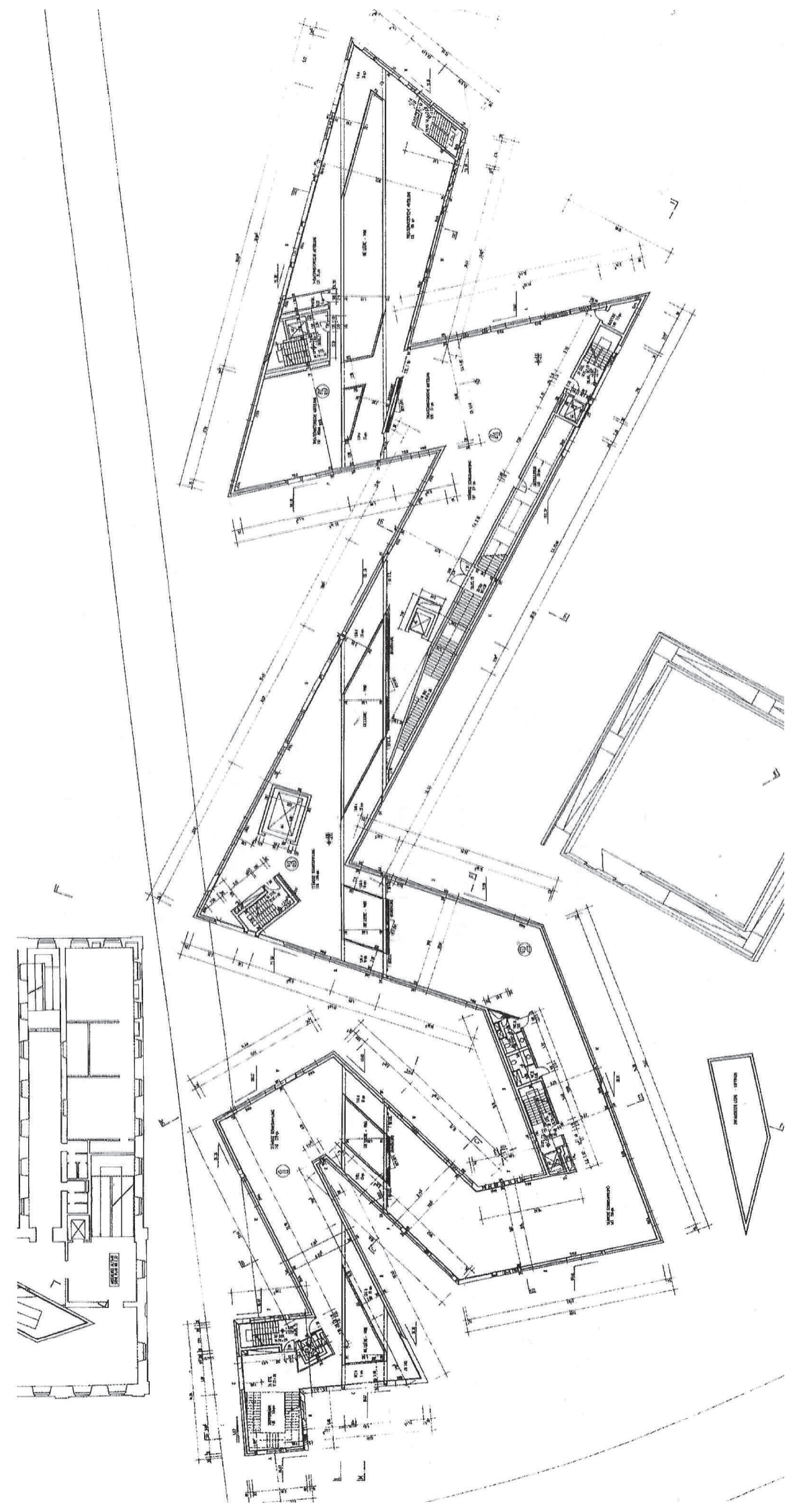

Il. 3. Plan poziomy Muzeum. Źródło: J.E. Young, At Memory’s Edge, s. 162 


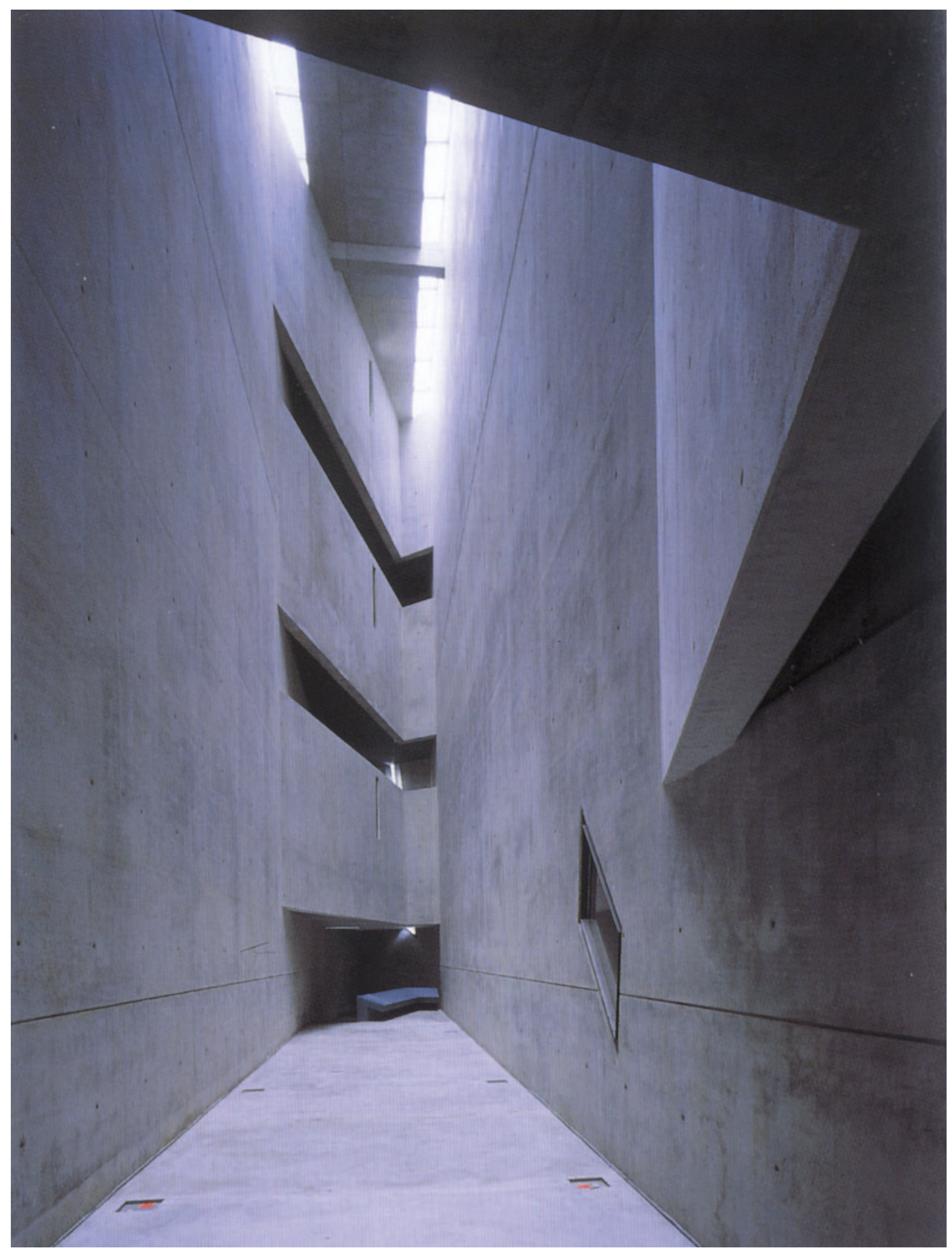

Il. 4. Przestrzeń Pustki. Źródło: B. Schneider, Daniel Libeskind. Jewish Museum Berlin, Munich-Berlin-London-New York 2005, s. 24 
jako architekta była i jest ochrona tej Pustki przed jej wypełnieniem, a przekonanie do tego komisji było jednym z najtrudniejszych zadań9.

W obecnej formie ta przestrzeń Pustki stanowi pięć oddzielnych części dzielących budynek wertykalnie i horyzontalnie. Pierwsze dwie części, w układzie od frontu budynku ( $\mathrm{tj}$. od ulicy Lindenstrasse), dostępne są z podziemnego przejścia. Dwie przestrzenie w środkowej części struktury budynku są absolutnie niedostępne, nie można do nich wejść, można jedynie do nich zajrzeć przez małe wertykalne otwory. W końcowej części muzeum znajduje się piąta, ostatnia Pustka, do której można znowu wejść od sal galerii czasowej ${ }^{10}$ [il. 4]. Owa pusta, przerywana oś, przecinająca więc całą konstrukcję, jest - można powiedzieć - bezużyteczną z wystawienniczego punktu widzenia przestrzenią. Ściany wyznaczające jej „granice” ważne są tu o tyle, o ile zakreślają pewien obszar w strukturze budynku.

Niemniej jednak dla bezpośredniego doświadczenia ta struktura osiowości jest nieuchwytna. Będąc wewnątrz budynku, nie sposób zorientować się, w których dokładnie miejscach wyznaczona jest ta pusta przestrzeń. Widziana jest tylko na planie i dopiero po zapoznaniu się z rozrysem przestrzennym orientujemy się co do jej lokalizacji ${ }^{11}$. Wymagana jest tu zatem uprzednia znajomość, wiedza, by mogła być dostrzeżona w ukończonej budowli. Nie wydaje się bowiem możliwe jej znalezienie (odczytanie) z samego tylko oglądu budynku zarówno z zewnątrz, jak i wewnątrz, przez niezaznajomionego z tą strukturą odbiorcę $^{12}$. Percepcja tej trochę poetycznej architektury wymaga swego rodzaju przygotowania, a jednocześnie - jak chce sam Libeskind - jest otwarta na interpretacje $\mathrm{e}^{13}$.

Tym samym część podjętych w literaturze przedmiotu objaśnień traktuje ów kluczowy aspekt „braku” w architekturze jako „przestrzeń” interpretacyjnie odnoszącą się do nieobecnych już Żydów berlińskich. Jak pisze dla przykładu

${ }^{9}$ Discussion (Derrida, Libeskind, Kipnis, Ingraham), [w:] D. Libeskind, A.P.A. Belloli, Daniel Libeskind, Radix-Matrix: Architecture and Writings, Munich-New York 1997, s. 115.

${ }^{10}$ D. Libeskind, Trauma, s. 57.

${ }^{11}$ Zob. E. Rewers, Doświadczenie pamięci, doświadczenie pustki, [w:] T. Majewski, A. Zajdler-Janiszewska (red.), Pamięć Shoah. Kulturowe reprezentacje i praktyki upamiętnienia, Łódź 2009, s. 581-593 oraz tejże: Pustka i forma, [w:] ibidem, s. 595-603.

${ }^{12}$ Zob. też: J.K. Lenartowicz, Architektura trwogi, [w:] Pamięć Shoah, s. 605-616; M. Popczyk, Przestrzenie pamięci: żydowskie muzea Daniela Libeskinda, [w:] ibidem, s. 629-636.

${ }^{13}$ Jak pisze Libeskind w cytowanej już autobiografii „Przełom”: „Zawsze postrzegałem budowlę jak rodzaj tekstu, którego przeznaczeniem jest być odczytywanym”, s. 75. 
Rolf Bothe: „te Pustki są wcieleniem bezkresnej utraty świata żydowskiego, który kiedyś nadawał kształtu Berlinowi. Każda $\mathrm{z}$ tych Pustek jest więc memoriałem czasów prześladowań i czyni tę żydowską historię niewidzialną"14. Jest to oczywiście pierwszy, jakby automatyczny poziom interpretacji, który jednak z konieczności pociąga za sobą dalsze implikacje analityczne, aczkolwiek podejmowane zarówno przez szereg teoretyków architektury, jak i przez samego Libeskinda ${ }^{15}$. „Ta historyczna fatalność niemiecko-żydowskich relacji kulturowych w Berlinie - jak pisze Libeskind - rozgrywa się teraz za zasłoną. I to oddalenie pragnę właśnie uczynić świadomym. Muzeum w takim miejscu jak Berlin nie można postrzegać zaledwie jako miejsce dla współczesnych mieszkańców, ale musi być też przestrzenią dla tych - powiedzmy metaforycznie - z przeszłości i przyszłości” 16 .

Zdaniem wspomnianego wyżej Bothe ów utracony, wykluczony i zniszczony świat żydowski właściwie wymyka się klasycznej koncepcji muzeum jako miejsca przeznaczonego do prezentacji ${ }^{17}$. Z kolei według Jamesa Younga w każdym innym muzeum, gdy oglądamy wystawę, obiekty są tym, co widzimy, ale tutaj Libeskind próbuje przebić tę muzeologiczną iluzję. To, czego tu doświadczamy — jak próbuje się za architekta wypowiedzieć Young — jest zaledwie maską dla tego, co właściwie nieobecne, brakujące i niemożliwe do pokazania ${ }^{18}$. Ta Pustka - jak pisze w innym miejscu Young — staje się uchwytna tylko przez

${ }^{14}$ [the voids are an embodiment of the emptiness, the lost world of the Jews, which had ones shaped Berlin. Each body of space becomes a memorial to era of persecution, making Jewish history invisible]. R. Bothe, The Berlin Museum and its Extension, [w:] Extension to, s. 36.

${ }^{15}$ Takie proste założenie byłoby zwykłym lub niebezpiecznym „u-pomnikowaniem”, co omawiane jest w dalszej części tekstu. W literaturze polskojęzycznej ów problem muzealnej Pustki analizowany w kategoriach innych niż tylko przez odniesienie do relacji po "nieobecnych” podejmowany jest przez: E. Rewers, Doświadczenie pamięci, doświadczenie pustki; J. Lubiak, O nowy kształt pamięci. Muzeum Żydowskie w Berlinie. Oba teksty opublikowane w: Pamięć Shoah, s. 595-603, 619-627. Zob. także: E. Domańska, „Niechaj umarli grzebią żywych”. Monumentalna przeciw-Historia Daniela Libeskinda, Teksty Drugie 1-2, 2004, s. 78-102.

${ }^{16}$ [The past fatality of the German Jewish cultural relation in Berlin is enacted now in the realm of the invisible. It is this remoteness which I have tried to bring to consciousness. The museum for such a place as Berlin should not only be for the citizens of the present, but should be accessible, let's say imaginatively or metaphysically, to citizens of the past and of the future, a place for all citizens, a place to confirm a common heritage]. D. Libeskind, Between the Lines, [w:] Extension to..., s. 58.

${ }^{17} \mathrm{R}$. Bothe, The Berlin Museum, s. 44.

${ }^{18}$ J.E. Young, At Memory's Edge. After-Image of the Holocaust in Contemporary Art and Architecture, New Haven-London 2000, s. 179. 
świadomość tego, co już nieuchwytne ${ }^{19}$. Jest strukturalnym żebrem, główną osią, centralnymi nośnymi murami zawierającymi tylko swoją Pustkę. I jest to pryncypialny element tej architektury ${ }^{20}$. Także zdaniem Very Bendt Pustka ta powinna być symbolem samym w sobie (samym przez się), jednak z konieczności „symbolizuje” też niemożliwość adekwatnej i jednoznacznej interpretacji historii po wydarzeniach Holokaustu językiem architektury ${ }^{21}$. Nieobecni Żydzi nie są tu jakimś nieobecnym obiektem, ale brakującym podmiotem, i ten fakt przysparza największych trudności współczesnej kulturze wizualnej, w tym $\operatorname{architekturze}^{22}$. Niemniej jednak ta Pustka — jak pisze Bendt — jest dziś nieodłącznym komponentem historii Berlina ${ }^{23}$.

Jacques Derrida w rozmowie z Libeskindem zauważa, że ta muzealna struktura Pustki przywodzi na myśl Freudowską koncepcję unheimlich, ewokującą ideę pamięci Shoah jako „jakiegoś nienazywalnego sekretu, jakąś kryptę lub nieświadomość czy «zapieczętowaną pamięć»"24. Otóż termin unheimlich jest pojęciem psychologicznym wypracowanym przez Sigmunda Freuda w ostatnich latach XIX w. jako rezultat jego własnego, niespodziewanego doświadczenia wizualnego podczas podróży pociągiem. W odbiciu szklanych drzwi Freud zobaczył mężczyznę, którego wygląd wydał mu się znajomy, ale jednocześnie niepokojąco obcy, dziwny, a nawet odpychający. Po chwili dopiero rozpoznał, że jest to jego własne odbicie i obrazuje jego „sekretną", „ukrytą” żydowskość; coś, co powinno zastać wewnętrzne, ale ujawniło się jako pewna „negatywna” refleksja ${ }^{25}$. Zatem

${ }^{19}$ J.E. Young, Daniel Libeskind's New, s. 50.

${ }^{20}$ Young w tym kontekście przywołuje także tekst Andreasa Huyssena: The Voids of Berlin, Critical Inquiry 24, 1, 1997, s. 57-81. J.E. Young, Daniel Libeskind's New, s. 50. Zob. też: A. Huyssen, Berlińskie Pustki, tłum. J. Mostowska, [w:] M. Saryusz-Wolska (red.), Pamięć zbiorowa i kulturowa. Współczesna perspektywa niemiecka, Kraków 2009, s. 432-457.

${ }^{21}$ V. Bendt, The Model of Integration, [w:] Extension to, s. 29.

${ }^{22}$ Ibidem, s. 30; J.E. Young, Daniel Libeskind's New, s. 50.

${ }^{23} \mathrm{~V}$. Bendt, The Model of, s. 25.

${ }^{24}$ [kept as a crypt or as an unconscious, which is encrypted here, [...] as a sealed memory]. Ponadto Derrida zwraca uwagę, że istnieją tu dwa rodzaje pustki - jedna, do której możemy wejść, i druga, która jest „zapieczętowana”; jednak obie pustki strukturalnie zazębiają się nawzajem. J. Derrida, Discussion, s. 115.

${ }^{25}$ S. Freud, The Uncanny (Das Unheimliche), [w:] The Standard Edition of the Complete Psychological Works of Sigmund Freud, red. i tłum. J. Strachey, 17, London 1995, s. 248-249 (217-256), przyp. 1. Zob. też: Niesamowite, [w:] S. Freud, Pisma psychologiczne, tłum. R. Reszke, 
unheimlich stanowi represyjną i pejoratywną, ale jednocześnie immanentną, nieredukowalną i nieuniknioną reprezentację stłamszonego elementu tożsamości; jest wszystkim tym, co powinno być sekretem i ukryte, ale zostaje wyjawione, pokazane i uświadomione ${ }^{26}$. Warto zauważyć że Derrida w tym dialogu odnosi się także do postulatu Libeskinda o żydowsko-niemieckim pojednaniu, nazywając je żydowsko-niemiecką psychika ${ }^{27}$, ale zaznacza jednocześnie, że ma tu na myśli nie tylko pojęcie $d u s z y$, ale także znaczenia francuskiego słowa lustro (miroare, ang. mirror) ${ }^{28}$.

Otóż unheimlich, tłumaczone z języka niemieckiego jako niesamowite, jest antonimem terminu heimlich oznaczającego (po)tajemny, skryty i przytulny, aczkolwiek wyprowadzone zostaje od rzeczownika Heim, czyli - dom (rodzinny), w którym asocjacje architektoniczne nie są przypadkowe. To freudowskie unheimlich (tłumaczone z kolei na język angielski jako uncanny) stanowi ważny przedmiot we współczesnej debacie architektonicznej, a sugestia Derridy nie jest w tej refleksji odosobniona. W tym miejscu należy podkreślić, że do koncepcji unheimlich w kontekście architektury (w tym do budowli Libeskinda) odnoszą się też inni teoretycy i filozofowie, jak Mark Wigley, Anthony Vidler, Mark C. Taylor czy wspomniany już James E. Young ${ }^{29}$.

Warszawa 1997. Aspekt ten, w kontekście tożsamości żydowskiej, omawiany jest także w: N. Mirzoeff, Inside/Out: Jewishness Imagines Emancipation, [w:] S. Tumarkin Goodman (red.) (kat. wyst.), The Emergence of Jewish Artists in Nineteeth-Century Europe, The Jewish Museum New York, New York 2002, s. 46-47; S. Gilman, Smart Jews. The Construction of the Image of Jewish Superior Intelligence, Lincoln-London 1996, s. 120 (rozdz. pt. Fin-de-Siecle Vienna and the Jewish Response to the Image, s. 103-143); S. Gilman, Love+Marriage=Death. And Other Essays on Representing Difference, Stanford, California 1998, s. 53, 109; R. Wistrich, Between Redemption and Perdition. Modern Antisemitism and Jewish identity, London 1990 (rozdz. 6: The Jewishjness of Sigmund Freud), s. 71-85; S.L. Braunstein, Sigmund Freud's Jewish Heritage, New York-London 1991, s. 13; D. Boyarin, Goyim Naches, or, Modernity and the Manliness of the Mentsh, [w:] B. Cheyette, L. Marcus (red.), Modernity, Culture and the Jew, Cambridge 1998, s. 63-64.

${ }^{26}$ Należy tu wyraźnie podkreślić, że unheimlich nie jest tym, co ukryte, ale tym, co powinno być ukryte, co ma być zamazane lub zakamuflowane, ale ujawnia się niezależnie i niespodziewanie. Zob. też: S. Volkov, Pomysł na nowoczesność. Żydzi niemieccy w XIX i na początku XX wieku, tłum. J. Górny, P. Pieńkowska, Warszawa 2006, s. 135. Tłumaczki przekładają tu jednak ten termin na „magiczne coś...”.

${ }^{27}$ [Jewish-German psyche] J. Derrida, Discussion, s. 115 (to charakterystyczne psyche zawiera w sobie według Derridy jakiś element niebezpieczny, rodzaj grozy. Zob. też: R. Lydenberg, Freud's Uncanny Narratives, PMLA 112, 1997, s. 1072-1086.

${ }^{28}$ J. Derrida, Response to D. Libeskind, [w:] Radix-Matrix, s. 111.

${ }^{29}$ Zob. też: B. van der Straeten, The Uncanny and the Architecture of Deconstruction, red. A. Masschelein, Image \& Narrative - Online Magazine of the Visual Narrative: Daniel 
Sugestia Derridy w rozmowie z Libeskindem wyartykułowana została w 1997 r., niemniej jednak - jak opisuje to M. Wigley w tekście pt. „U-domowienie domu" ${ }^{30}$ - twórca filozofii dekonstrukcji podejmuje ten wątek znacznie wcześniej, bo już w jednej z kluczowych publikacji „Pismo i różnica” (1967) ${ }^{31}$, a następnie w „Podwójnej sesji” (1981), gdzie objaśnia swoje „powtórne odczytanie” eseju Freuda Das Unheimliche właśnie w kategoriach i terminologii architektonicznej ${ }^{32}$. Ponadto, jak zauważa dalej Wigley, pomimo iż metafora domu nie jest przedmiotem jakiejś oddzielnej pracy Derridy, to jednak motyw ten pojawia się w jego twórczości permanentnie"33. Zestaw metafor architektonicznych w filozofii Derridy — jak pisze też Cezary Wąs — jest duży, „wszak już «dekonstrukcja» brzmi architektonicznie, a jej punktem wyjścia są przecież «konstrukcja» $\mathrm{i}$ «struktura» oraz Heideggerowska «krytyczna przebudowa»" ${ }^{44}$ (o czym poniżej).

S. Freud w „Podwójnej sesji” — zdaniem Derridy — zwraca uwagę na sposób, w jaki termin określający to, co domowe (heimlich), jest rozumiany zarówno jako „należący do domu, nie dziwny, znajomy, oswojony, bliski, przyjazny itp. i jako coś, co wydaje się z początku być tego całkowitym przeciwieństwem: ukryty, niedostępny dla wzroku, nieznany i odmawiany innym"35. Jest to opis niespokojnego przeczuwania tego, co nieznajome, w obrębie tego, co znajome;

Libeskind, www.imageandnarrative.be/inarchive/uncanny/bartvanderstraeten.htm. (dostęp: 12.11.2013)

${ }^{30} \mathrm{M}$. Wigley, The Domestification of the House: Deconstruction after Architecture, [w:] P. Brunette, D. Wills (red.), Deconstruction and the Visual Arts. Art, Media, Architecture, Cambridge University Press , Cambridge 1994, s. 203-227. Tekst pojawił się także w skróconej wersji jako rozdział książki M. Wigleya The Architecture of Deconstruction: Derrida's Haunt, Cambridge 1993. Polskie tłumaczenie części tekstu Wigleya (z której tu korzystam) zostało opublikowane przez: M. Pawlikowska, U-domowienie domu: Dekonstrukcja po Architekturze, [w:] B. Małczyński, R.Włodarczyk (red.), Czytanie Derridy, Wrocław 2005, s. 93-108.

${ }^{31}$ J. Derrida, Freud and the Scene of Writting, tłum. A. Bass, [w:] idem, Writing and Difference, Chicago 1978, s. 215 (196-231). Wyd. polskie: Pismo i różnica, tłum. K. Kłosiński, Warszawa 2004 (tytuł oryginału: Lécriture et la différence - 1967).

${ }^{32}$ J. Derrida, Double Sesion, tłum. B. Johnson, [w:] idem, Dissemination, Chicago 1981, s. 220 (173-285). M. Wigley, The Domestification, s. 216. Zob. też.: J. Derrida, Archive Fever: A Freudian Impression, tłum. ang. E. Prenowitz, Chicago 1996; M. Pawlikowska (tłum.), U-domowienie, s. 99-101.

${ }^{33}$ M. Wigley, The Domestification, s. 215. Zob. też: M. Pawlikowska (tłum.), U-domowienie, s. 99.

${ }^{34}$ C. Wąs, Zagadnienia interpretacji architektury w filozofii Jacquesa Derridy, [w:] Czytanie Derridy, s. 41.

${ }^{35}$ Cyt. za: M. Pawlikowska (tłum.), U-domowienie, s. 101. 
niepokojąca obecność niedomowego w obrębie domu ${ }^{36}$. M. Wigley w swoim eseju wyszczególnia też inne inspiracje Derridy, a mianowicie filozofię Platona, na podstawie której filozof dekonstrukcji postuluje, że „we wszystkich parach antonimicznych pojęć, które nadają porządek metafizyce, każde pojęcie musi być po prostu zewnętrzne w stosunku do drugiego, co oznacza, że jedno z tych przeciwstawnych pojęć (przeciwstawienie sobie wnętrza i zewnętrzności) musi już być uważane za matrycę wszelkiej możliwej przeciwstawności" ${ }^{37}$. Wynika stąd, że system filozoficzny (w tym teoria architektury) opiera się na metaforach przestrzennych, których nie może porzucić, i sam z siebie jest z konieczności przestrzenny $^{38}$.

Co więcej - jak zauważa dalej Wigley - twórczość Derridy wyrasta w znacznym stopniu z lektury zarówno „redukcji fenomenologicznej” Edmunda Husserla ${ }^{39}$, jak i z „krytycznej przebudowy” Martina Heideggera ${ }^{40}$. Heidegger był w 1920 r. uczniem Husserla i w tym czasie wypracował system interpretacji filozoficznej określany mianem „krytycznej przebudowy” (Kritischer Abbau), tłumaczonej też przez terminy „destrukcji” (Destruktion), „krytycznego de-montażu”, „krytycznej rozbiórki” czy wreszcie „de-konstrukcji”, tj. konstruowania-poprzez-de-montowanie ${ }^{41}$.

${ }^{36}$ Zob. też: N. Ellin, Shelter from the Storm or Form Follows Fear and Vice Versa oraz: A. Trautman, Secret Places and Hidden Space in Dwellings), oba teksty w: N. Ellin (red.), Architecture of Fear, New York 1995, s. 13-46; 143-158.

${ }^{37}$ J. Derrida, Palto’s Pharmacy, tłum. B. Johnson, [w:] idem, Dissemination, s. 103; M. Wigley, The Domestification, s. 213. Tłumaczenie cytatu za: M. Pawlikowska (tłum.), U-domowienie, s. 99.

${ }^{38}$ Zauważywszy, w jaki sposób system Freuda jednocześnie posługuje się metaforami przestrzennymi i poddaje je w wątpliwość, Derrida utrzymuje, że „pewien rodzaj przestrzenności nierozdzielny od samej idei systemu, jest nieredukowalny”. Za: M. Pawlikowska (tłum.), U-domowienie, s. 99.

${ }^{39}$ J.J. Kockelmans, A First Introduction to Husserl's Phenomenology, Pittsburg 1967; P. Ricoeur, Husserl: An Analysis of His Phenomenology, Evanston 1967. Zob. też: E. Husserl, [w:] G. Wigoder, Słownik biograficzny Żydów, tłum. A. Jaraczewski, I. Kałużyńska, P. Łomnicki, A.M. Nowak, B. Stokłosa, Warszawa 1998, s. 224.

${ }^{40}$ O. Pöggeler, Martin Heidegger’s Path of Thinking, tłum. D. Magurshak, S. Barber, New Haven 1987; R. Safranski, Martin Heidegger: Between Good and Evil, Cambridge, Mass. 1998; J. Derrida, Of Spirit: Heidegger and the Question, Chicago 1989.

${ }^{41}$ M. Wigley, The Domestification, s. 206; M. Pawlikowska (tłum.), U-domowienie, s. 95. Zob. też M. Heidegger, What is a Thing?, tłum. W.B. Barton, V. Deutsch, Chicago 1967, s. $123-$ 125. Wyd. polskie: Pytanie o rzecz, tłum. J. Mizera, Warszawa 2001; A. Benjamin, Ch. Norris, What is Deconstruction?, New York 1988. 
Z takiej perspektywy teoretycznej — jak pisze dalej Wigley, podążając zarówno za Derridą, jak i za Heideggerem - dalsze próby analiz i interpretacji architektonicznych „nie są już staniem na stabilnym gruncie (Grund), lecz staniem, które opiera się o utratę gruntu. Jest to «konstrukcja» zbudowana nad przepaścią (Abgrund)”. Niemniej jednak ta przepaść, czy też rozerwanie pierwotnego gruntu rzeczy (lub istoty, tj. przedmiotu i podmiotu filozofii, ale także teorii architektury), staje się niezbędna dla zaistnienia danego „przedmiotu/podmiotu" w ogóle ${ }^{42}$.

W kontekście powyższych zależności przestrzenno-teoretycznych i w odniesieniu do struktury budynku Libeskinda (także w analogii do złożoności interpretacji tego budynku) warto przywołać tu ciekawą sugestię wyprowadzoną przez Anthony’ego Vidlera. Otóż Vidler pisze, że Libeskind „kreuje architekturę, która zwyczajnie nie buduje przestrzeni ani kształtu przestrzeni, za to - trochę literalnie - buduje poza przestrzenią" ${ }^{43}$. Doświadczając tę „rozrysowaną” zewnętrznie bryłę i kłopotliwe wnętrze muzeum - jak pisze autor - znajdujemy się w świecie fenomenologicznym, w którym bez kłopotu odnaleźliby się zarówno Heidegger, jak i Sartre - tj. „nie do końca w domu” [if not exatly „at home”], w jakiejś niewygodnej sytuacji spowodowanej przez nieciągłe osie, rozdarte mury, niebezpiecznie przechylone, ukośne ściany, puste pomieszczenia i wobec zamaskowanych wejść i wyjśćc ${ }^{44}$. Jest to, jak pisze dalej Viler (za Heideggerem), doświadczenie „wpadnięcia do", niesamowitego, niemożliwego, niezadomowionego [falling into the uncanny] i za Sartreem - jest to doświadczenie niebezpiecznej instrumentalności obiektu, który wstrząsa zmysłami i ciałem ${ }^{45}$.

Derrida ponadto $\mathrm{w}$ rozmowie $\mathrm{z}$ architektem postuluje, że skoro pusta, zamknięta murami wewnętrzna przestrzeń muzeum jest czymś innym oprócz pustej, zaprojektowanej tam architektonicznej przestrzeni, to zasadniczo nie powinniśmy nazywać jej Pustką albo zastąpić ją innym słowem ${ }^{46}$. Libeskind natomiast odpowiada, że „jest to właściwie jedyna część budynku, która nie zo-

${ }^{42}$ M. Wigley, The Domestification, s. 206; M. Pawlikowska (tłum.), U-domowienie, s. 96.

${ }^{43}$ A. Vidler, Warped Space. Art, Architecture, and Anxiety in Modern Culture. Cambridge, Mass. 2000, s. 237 (236-242). Problematykę unheimlich A. Vidler podjął także w książce pt.: The architectural uncanny: Essays in the Modern Unhomely, Cambridge, Mass. 1992.

${ }^{44}$ A. Vidler, Warped Space, s. 238.

${ }^{45}$ Ibidem, s. 239-240.

${ }^{46}$ [There is some emptiness surrounded by a line which is indivisible, a circumscribed emptiness. So if the void is not this, then perhaps we have to give up the void, or give up the word 'void']. J. Derrida, Response to Daniel Libeskind, [w:] Radix-Matrix, s. 114. 
stała w techniczny sposób zaprojektowana. To jest jedyna część budynku, która została ukonstytuowana przez naszą o niej wiedzę, przypuszczenie, przeczucie i wiarę. Nie jest to coś celowo, z zamiarem zaprojektowanego. To po prostu tam jest" ${ }^{47}$. W innym miejscu z kolei architekt pisze, iż „ta konkretna struktura właściwie nie ma żadnej nazwy, ponieważ jej (Pustki) przedmiotem nie są jej mury, ale przestrzeń (Pustka) tam «zawinięta», «zapakowana»; zawarte jest tam owo «między liniami»" $" 48$.

Zatem to "architektoniczne" unheimlich w sugestii Derridy odnosi się do wydarzeń historycznych i zakresu pamięci Holokaustu, i jest czymś, czego nie można zepchnąć do jakiejś nieświadomości. Termin heimlich, czyli u-domowione (w relacji do terminów pamięci i architektury), oznacza coś, co jest w pełni „oswojone”, „zaadaptowane”, a także przyjazne i bliskie. „W tym strukturalnym prześlizgnięciu od heimlich do unheimlich - jak pisze z kolei M. Wigley - to, co rzekomo leży poza znajomą pociechą domu, okazuje się zamieszkiwać ów dom przez cały czas. Wypływa jednak na powierzchnię jedynie podczas powrotu tego, co zostało stłamszone jako obcy element. W dziwny sposób element ów zdaje się należeć właśnie do domeny, która nadaje mu charakter obcości” ${ }^{49}$. W innym miejscu Wigley zauważa, że ta "niesamowitość jest wpisana w to, co wydaje się najbardziej znajome, najbardziej domowe, [...] ale okazuje się, że zarówno pozorna bliskość domu, jak i wrażenie, że jest on dobrze znany, są bardzo zwodnicze. W tym niby znajomym wnętrzu mieszka niepokojąca niesamowitość ${ }^{50}$.

Pamięci Holokaustu nie można „udomowić”, dlatego też Pustka w muzeum ma nieustannie "straszyć” [haunt], ma być jakąś wynurzającą się trwogą, a więc musi pozostać nie-u-domowiona i tym samym ma zawierać także własności anty-pomnika. Termin ten (anty-pomnik) został zainicjowany

${ }^{47}$ [it is not something that is designed deliberately. It is already there]. Discussion, s. 115.

${ }^{48}$ D. Libeskind, 1995 Raoul Wallenberg Lecture, An Arbor, Mich. College of Architecture and Urban Planning, 1995, s. 35. Cyt. za: J.E. Young, At the Memory's Edge. After Image of the Holocaust in Contemporary Art and Architecture, New Haven-London 2000, s. 175.

${ }^{49}$ M. Wigley, The Domestification, s. 216, tłum. za: M. Pawlikowska (tłum.), U-domowienie, s. 101.

${ }^{50}$ M. Wigley, The Architecture of, s. 108, za: M. Pawlikowska, Myśl Derridy a architektura postmodernistyczna (dekonstrukcja - poza konstrukcją i destrukcją), [w:] Czytanie Derridy, s. $39(35-40)$. 
i rozpropagowany w szeregu publikacji przez J.E. Younga, który w swych analizach wychodzi od krytyki tradycyjnego (rzeźbiarskiego, pełnoplastycznego) monumentu, powołując się na teksty Fryderyka Nietzschego, Lewisa Mumforda, Roberta Musila, Martina Broszata i Pierre’a Nory ${ }^{51}$. Otóż tradycyjny pomnik - zdaniem Younga - swoją materialną formą zastępuje kultywowanie pamięci w danej społeczności, i zamiast ją ucieleśniać, to właściwie ją wypiera. Przywołując słowa P. Nory, według którego „Im mniej pamięci doświadczamy od wewnątrz, tym bardziej istnieje ona poprzez swoje zewnętrzne rusztowania i znaki"'52, Young sugeruje tu stwierdzenie odwrotne: „im więcej pamięci spoczywa w uzewnętrznionych formach, tym mniej doświadczamy jej wewnętrznie, [...] przejmując na siebie rolę kultywowania pamięci, pomniki zdają się uwalniać widzów od jej brzemienia"53. W tym kontekście znamienne są również słowa R. Musila, który pisał: „Nie ma na tym świecie nic bardziej niewidocznego niż pomnik. Niewątpliwie buduje się je, aby były widoczne - a nawet by zwracały uwagę. Jednocześnie jednak przesyca je coś, co uwagę odpycha" ${ }^{54}$. Generalnie - tradycyjne pomniki, będąc częścią rytuałów narodowych, państwowych czy historycznych, przyjmują rodzaj formy wyidealizowanej i stanowią moduł narzuconej interpretacji tzw. historii monumentalnej ${ }^{55}$. Tym samym, jak pisze Young,

${ }^{51}$ J.E. Young, Pamięć i kontrpamięć. W poszukiwaniu społecznej estetyki pomników Holokaustu, tłum. G. Dąbkowski, Literatura na Świecie 1-2, 2004, s. 267-289. Tekst ten jest tłumaczeniem fragmentu książki J.E. Younga pt.: The Texture of Memory: Holocaust Memorials and Meaning, New Haven 1993, s. 17-48. Zob. także: J.E. Young, Memory and Counter-Memory: Towards a Social Aesthetic of Holocaust Memorials, [w:] M. Bohm Duchen (red.), After Auschwitz: Responses to the Holocaust in Contemporary Art, London 1995, s. 78-102. Szczegółowe omówienie niemieckich anty-pomników zawarte zostało w: J.E. Young, The Counter-monument: Memory Against Itself in Germany Today, Critical Inquiry 267, 1992.

${ }^{52}$ P. Nora, Between Memory and History: Les Lieux de Memoire, tłum. M. Roudebish, Representations 13, 1989. Za: J.E. Young, Pamięć i kontrpamięć, s. 273.

${ }^{53}$ Ibidem, s. 273-274.

${ }^{54}$ R. Musil, Monuments, [w:] idem, Posthumous Papers of a Living Author, tłum. P. Wortsman, Hygiene, CO, 1987, s. 61; J.E. Young, Pamięć i kontrpamięć, s. 286.

${ }^{55}$ Jak pisze dalej Young: „Monumentalna historia była pogardliwym epitetem Nietzschego dla każdej wersji historii mieniącej się stałą i nieprzemijającą, dla historii spetryfikowanej, historii, która grzebie żywych". F. Nietzsche, Pożyteczność i szkodliwość historyi dla życia, tłum. L. Staff, [w:] Dzieła Nietzschego, XIII, Warszawa 1912, s. 110-116. J.E. Young, Pamięć i kontrpamięć, s. 271-272. „Przyjmując wyidealizowane formy i znaczenia nadane im przez państwo, pomniki konkretyzują najczęściej określoną interpretację historii”. J.E. Young, Pamięć i kontrpamięć, s. 273. 
„Tradycyjne założenie o ponadczasowości pomnika zepchnęło go jako formę niemal na margines współczesnego dyskursu. [...] Utrzymując, że ucieleśniona w nim pamięć jest tak niezmienna jak miejsce w krajobrazie, pomnik zdaje się ignorować naturalną zmienność wszystkich przedmiotów kultury materialnej" ${ }^{56}$. Potwierdzeniem dla Younga są również słowa krytykującego monumentalizm L. Mumforda, według którego idei pomnika nie można pogodzić z koncepcją współczesnych form architektonicznych ${ }^{57}$, gdyż przeczy on „samej istocie nowoczesnej cywilizacji miejskiej: jej zdolności do odradzania i odmładzania się ${ }^{58}$.

Zatem w obliczu istotnych kwestii niemieckiej historii XX w., współczesnej polityki państwa oraz kulturowych postulatów pamięci ${ }^{59}$ Young sugeruje, że jedną z najlepszych odpowiedzi jest właśnie pojawienie się anty-pomników ${ }^{60}$, stanowiących afirmatywną kontestację własnego istnienia, a tym samym podejmujących kluczowe wyzwanie dla (współczesnej) świadomości historycznej. Autor przywołuje (i analizuje w swoich tekstach) szereg takich niemieckich twórców, jak Jochen Gerz, Norbert Radermacher, Horst Hoheisel i Hans Haacke, a także artystów i architektów amerykańskich pracujących w Niemczech, jak Sol Lewitt, Shimon Attie czy właśnie Daniel Libeskind ${ }^{61}$.

${ }^{56}$ Pomniki „próbują się przedstawić jako autochtoniczne, czy wręcz geologiczne, składowe narodowego krajobrazu: z czasem, taka wyidealizowana pamięć staje się dla oka równie naturalna, jak sam krajobraz, w którym się znajduje”. J.E. Young, Pamięć i kontrpamięć, s. 271-272.

${ }^{57}$ „Pojęcie nowoczesnego pomnika — zdaniem Mumforda — jest całkowicie sprzeczne samo w sobie. Jeśli obiekt jest pomnikiem, to nie jest nowoczesny, a jeśli jest nowoczesny, to nie może być pomnikiem". L. Mumford, The Culture of the Cities, New York 1938, s. 438. Za: J.E. Young, Pamięć i kontrpamięć, s. 272.

${ }^{58}$ „Podczas gdy nowoczesna architektura wzywa do podtrzymywania życia, odnowy i zmian, odrzucając iluzję stałości, «kamień daje fałszywe poczucie ciągłości i złudną gwarancję życia»”. Za: J.E. Young, Pamięć i kontrpamięć, s. 272.

${ }^{59}$ Kluczową publikacją z tej tematyki jest książka napisana pod redakcją Magdaleny Saryusz-Wolskiej Pamięć zbiorowa i kulturowa. Współczesna perspektywa niemiecka, Kraków 2009 (zwłaszcza „Wprowadzenie” tejże, s. 7-38).

${ }^{60}$ Autor przekładu tekstu Younga proponuje termin „kontrpomnik” (J.E. Young, Pamięć i kontrpamięć, s. 278), jednak odpowiedniejszy wydaje się zwrot „anty-pomnik”.

${ }^{61}$ J.E. Young, Pamięć i kontrpamięć, s. 278. Zob. także: idem, The Arts of Jewish Memory in a Postmodern Age, [w:] B. Chayette, L. Marcus (red.), Modernity, Culture and the Jew, Cambridge 1998, s. 211-225; M. Winzen, The Need for Public Representation and the Burden of German Past, Art Journal 309, 1989; I. Rogoff, The Aesthetics of Post-History: A German Perspective, [w:] S. Melville, B. Readings (red.), Vision and Textuality, Durham 1995, s. 115-140. 
W tym kontekście należy też podkreślić, że owej Pustki Libeskinda (jako unheimlich) nie można wykorzystać do celów wystawienniczych; jest czymś, czego nie da się oswoić, naruszyć, zaadaptować, a więc musi pozostać drażniąco „obca”. J. Young w swojej analizie struktury budynku, której nadaje podtytuł „The Uncanny Arts of Memorial Architecture”, zauważa, że jest to „architektura pamięci”, która zaprasza nas do swojego pozornie gościnnego otoczenia po to, aby zrazić nas do siebie tuż po wejściu ${ }^{62}$. Dlatego też to niesamowite, pełniące funkcję upamiętniającą, może być uznane za to, co anty-zbawcze. „To właśnie ta pamięć o wydarzeniach historycznych nigdy nie udomawia tych wydarzeń, nigdy nie pozwala nam poczuć się z nimi swobodnie, nigdy nie umiejscawia ich w uspokajająco-zbawiennym kontekście. Jej przeznaczeniem jest pozostawienie tychże wydarzeń jako niedających się odkupić [...]”63. Ta „niesamowita architektura pamięci” jako „metafora nieznośnego stanu (ducha)" jest — zdaniem Younga - najlepszym opisem relacji dzisiejszych Niemiec ze swoją żydowską przeszłością ${ }^{64}$. Jest jakimś negatywnym centrum ciężkości, wokół którego żydowska pamięć się teraz koncentruje ${ }^{65}$. Niemniej jednak, według Younga, Libeskind nie sugeruje tu, jakoby ta elementarna i stanowiąca kluczowy aspekt kondycji żydowskiej po Holokauście Pustka pochodziła z zewnątrz (jako narzucona na Berlin), ale niejako wychodzi ze środka tego miasta (jak unheimlich) ${ }^{66}$. Przypomina o jakiejś otchłani, w którą ta cała struktura została właściwie zatopiona i jednocześnie $z$ której się jakby próbuje wynurzyć ${ }^{67}$. Sam Libeskind określa ową strukturę jako „zamaskowane, mistyczne przejście”, „zamkniętą salę bez klucza” czy jako „kafkowską górę we mgle” ${ }^{68}$.

${ }^{62}$ J.E. Young, At Memory's Edge, s. 154.

${ }^{63}$ Ibidem, s. 154-155.

${ }^{64}$ Zob. też: S.L. Gilman, Jews in Today's German Culture, Bloomington-Indianapolis 1995, s. 27-31.

${ }^{65} \mathrm{~J} . \mathrm{E}$. Young, At Memory's Edge, s. 154.

${ }^{66}$ Ibidem, s. 165.

${ }^{67}$ Ibidem, s. 180.

${ }^{68}$ D. Libeskind, The Myth of Site, [w:] Radix-Matrix, s. 140. Zob. też: D. Libeskind, Line of Fire, 1-2, Geneva-Milan (International Labour Organization \& Electa Spa) 1988. Książka nie zawiera numerów stron i składa się z tekstów, rysunków i fotografii Libeskinda, z przedmowy Adeliny von Furstenberg i C. Bruce'a Dunninga oraz wprowadzenia napisanego przez Aldo Rossiego. 
Ponadto w rozmowie z Derridą architekt podkreśla, że ta zamknięta Pustka powoduje, iż nikt ze zwiedzających po wyjściu z muzeum nie może prawdziwie powiedzieć, że tam był, że to widział ${ }^{69}$. Takie założenie odnosi się oczywiście do pojęcia „niemożliwego doświadczania architektury”, implikowanego tu jako charakterystyczny, świadomy postulat koncepcji dekonstruktywistycznych w architekturze. W tekście pt. „Trauma” (termin sugestywnie przywołujący znaczenia unheimlich) Libeskind tłumaczy, że doświadczenie architektury może być omawiane z perspektywy zarówno jakiegoś ujęcia konceptualnego, jak i konkretnej rzeczywistości, aczkolwiek obie te perspektywy uzmysławiają nam niemożliwość doświadczenia explicite i tym samym ewokują swego rodzaju wyrwę w naszej świadomości (w naszej percepcji) ${ }^{70}$. Przypominają nam zasadniczą różnicę między zaledwie symulacją doświadczenia (doświadczania) a doświadczeniem jako takim; doświadczenie historii — jak pisze Libeskind — jest relacją między pustką a pewną nieobecnością, która nie jest tu zaledwie relatywna, lecz „katastroficzna" i przede wszystkim absoluta, a-historyczna ${ }^{71}$. Ta Pustka - jak pisze dalej architekt - jest swego rodzaju dekonstruktywistycznym otwarciem (traumą), przerwą, przecięciem, ale też nieokreślonym dystansem czy nawet brakiem architektury lub „architekturą wycofaną”, „wygnaną"72.

Ten wykorzystywany nader często w literaturze przedmiotu termin (wygnanie), utożsamiony z pojęciem diaspora ${ }^{73}$, tłumaczony jest na język hebrajski jako gola. Otóż gola, lub galut, jest określeniem religijnym, teologicznym, oznaczającym właśnie wygnanie (z centrum, z domu), a także wykorzenienie, dyslokację, przebywanie w nieodpowiednim, miejscu i odnosi się do charakterystycznych wartości ontologicznych oraz sytuacji egzystencjalnej ${ }^{74}$. Galut,

${ }^{69}$ Discussion, s. 113.

${ }^{70}$ D. Libeskind, Trauma, s. 43-45.

${ }^{71}$ „Ten a-historyczny wymiar pustki — jak pisze Libeskind - ciągle mnie nurtuje. Ta pusta przestrzeń, dziura w historii, musi być jakoś w tej architekturze połączona, ale jak? [...] zacznijmy więc od początku, od punktu zero. [...] jest to kwestia etyki architektonicznej i zadań stojących przed tą architekturą". D. Libeskind, Trauma, s. 46-47.

${ }^{72}$ Idem, Trauma, s. 47.

${ }^{73}$ Określenie diaspora jest nazwą grecką, której brak tradycyjnego ekwiwalentu w języku hebrajskim. Termin ten po raz pierwszy pojawił się w Encyclopedia Britannica w 1876 r. na określenie rozproszenia (zwłaszcza Żydów) na świecie; jest desygnatem politycznym i oznacza rozproszenie geopolityczne. Zob. np.: H. Wettstein, Coming to Terms with Exile, [w:] idem (red.), Diaspora \& Exiles. Varieties of Jewish Identity, London 2002, s 47.

${ }^{74}$ Y.F. Baer, Galut, New York 1947; A. Eisen, Galut: Modern Jewish Reflection on Homelessness and Homecoming, Bloomington 1986. 
Wygnanie czy Diaspora - jak zauważa Howard Wettstein — jest powszechnym lub nawet dominującym aspektem żydowskiej historii; jest statusem życia w diasporze, czyli na wygnaniu ${ }^{75}$.

Mając to na uwadze, warto na koniec przywołać - wykorzystującą także termin unheimlich - ciekawą analizę struktury Pustki Libeskinda dokonaną przez Marka M. Taylora. Mianowicie Taylor w swoim niezwykle zawiłym, skomplikowanym i wieloznacznym tekście celowo zamienia termin unheimlich właśnie na wygnanie, natomiast do terminu Pustka (Void) dodaje przedrostek „a”, tworząc słowo a-voiding (unikanie, omijanie). Budowanie dekonstruktywne - jak pisze autor - mogłoby być budowaniem Pustki bez opróżniania (lub unikania) budynku/lub bez unikania budowania [to construct deconstructively would be to build voids without a-voiding building ${ }^{76}$. Jest mimo wszystko możliwe, że ta Pustka nie jest destrukcyjna (czymś destrukcyjnym), nie stając się konstruktywną, aczkolwiek ma ewokować pewien stan umysłu (unheimlich $)^{77}$. Uświadomienie sobie freudowskiego unheimlich (zamienionego tu na „wycofanie") wywołuje poczucie bycia niejako na wygnaniu (w zagubieniu). Być Żydem (we współczesnych Niemczech), jak Taylor przywołuje za Edmondem Jabesem, to „wczesne opuszczenie domu i udanie się do-nikąd” [to have left home ealary and arrived no-where]. Ale w dalszym komentarzu do Jabesa pisze: „to udanie się do-nikąd (no-where) jest oczywiście zostaniem na miejscu. [...] Wygnanie jest więc nie do przebycia. W tym nieskończonym nigdzie (do-nikąd - nowhere) znajduje się owo "wyparte» błądzenie/zagubienie" [between the infinite no's of where lies the dis-place of erring $]^{78}$. Ten złożony postulat jest więc sugestywną aluzją teoretycznego (czy symbolicznego) przejścia od tragicznych wydarzeń historycznych do współczesnej, społeczno-psychologicznej i kulturowej kondycji Niemiec oraz perspektywy dla współczesnych Żydów niemieckich. Jeśli berlińskie, muzealne unheimlich jest unheimlich Freudowskim - jak pisze z kolei J. Young — to żaden inny termin nie określa lepiej współczesnej kondycji

${ }^{75} \mathrm{H}$. Wettstein, Coming to Terms with Exile, [w:] idem (red.), Diaspora \& Exiles, s. 47-48.

${ }^{76}$ M.C. Taylor, Point of No Return, [w:] Radix-Matrix, s. 131.

${ }^{77}$ Mark C. Taylor, Point of, s. 131. Zdaniem Petera Eisenmana miejsce, na którym wznosi się nową budowlę, nigdy nie jest czystą kartą. Kiedy je zastajemy, jest już naznaczone pewną historią, która nawiedza to miejsce jak jakiś duch. To tutaj właśnie kryje się niesamowitość, derridiańska „widmowość" (la spectralite) tego miejsca. Eisenman twierdzi, że architekt powinien dostrzec ślady tej historii i włączyć je w swoją architektoniczną całość. Za: M. Pawlikowska, Myśl Derridy, s. 40.

${ }^{78}$ M.C. Taylor, Point of, s. 131. 
kultury Niemiec, zmagających się z „uciążliwą” Pustką w samym środku stolicy — przerażającą Pustką, która jest sekretnie znajoma i jednocześnie utajona ${ }^{79}$.

\section{Artur Kamczycki \\ UNHEIMLICH: STRUCTURES OF THE VOID IN LIBESKIND'S JEWISH MUSEUM IN BERLIN}

\section{Summary}

The Museum of 2000 years of German-Jewish History in Berlin, designed in 1988 by Daniel Libeskind, an architect of Polish origins, was to make a powerful reference to the Holocaust as well. Using an underground passage, the architect connected the existing Baroque edifice of the Kollegienhaus in Kreuzberg's Lindenstrasse, with the building created to his design (the so-called Abteilung). The external form of the buildings is a steel, flat-topped structure, composed of cubical blocks, irregular and marked by incisive edges. Inside, this zig-zagging building was intersected by a straight structure, $4.5 \mathrm{~m}$ wide, $27 \mathrm{~m}$ high and 150 long, which runs interruptedly along the main axis. The resulting empty spaces, extending from the ground floor to the roof, are tightly isolated from the remaining sections of the edifice. The analysis conducted by the author targets the comparison of that structure of the Void with the Freudian notion of the Unheimlich (uncanny). The comparison was made in a conversation with Libeskind by the originator of the theory of deconstruction, Jacques Derrida. Unheimlich is a psychological notion, which in this case denotes "secret", "hidden" Jewishness, which instead of remaining an "internally closed" aspect is manifested as a characteristic, "negative" reflection. The term, entangled in the context of architectural theory as well as in the notion of anti-monument, represents a starting point in considering the contemporary condition of German culture, where that Void/unheimlich is a constant, "burdensome" echo of the Holocaust.

${ }^{79}$ J.E. Young, At Memory's Edge, s. 183. Zob. też: N. Wood, The Victim's Resentments, [w:] Modernity, Culture, s. 257-267; R.S. Wistrich, Xenophobia and Antisemitism in the New Europe: The Case of Germany, [w:] idem (red.), Demonizing the Other. Antisemitism, Racism and Xenophobia, Jerusalem 1999, s. 349-363; J.M. Peck, Being Jewish in the New Germany, New Brunswick 2006; S.L. Gilman, Jews in Today's German Culture, Bloomington-Indianapolis 1995; L. Morris, J. Zipes (red.), Unlikely History. The Changing German-Jewish Symbiosis, 1945-2000, New York 2002. 


\section{Bibliografia}

Baer Y.F., Galut, New York 1947.

Bendt V., The Model of Integration, [w:] K. Feireiss (red.), Daniel Libeskind: Erweiterung des Berlin Museums mit Abteilung Jüdisches Museum/Daniel Libeskind: Extension to the Berlin Museum with Jewish Museum Department (katalog niem./ang.), Berlin 1992, s. 24-31.

Benjamin A., Norris C., What is Deconstruction?, New York 1988.

Bothe R., Bendt V., Realisierung Wettbewerg: Eweiterung Berlin Museum mit Abteilung Jüdisches Museum, Berlin: Senatsverwaltung für Bau- und Wohnungswesen, 1990.

Bothe R., The Jewish Museum and ist Extention, [w:] K. Feireiss (red.), Daniel Libeskind: Erweiterung des Berlin Museums mit Abteilung Jüdisches Museum/ Daniel Libeskind: Extension to the Berlin Museum with Jewish Museum Department (katalog niem./ang.), Berlin 1992, s. 33-52.

Boyarin D., Goyim Naches, or, Modernity and the Manliness of the Mentsh, [w:] B. Cheyette, L. Marcus (red.), Modernity, Culture and the Jew, Cambridge 1998, s. 63-90.

Braunstein S.L., Sigmund Freud's Jewish Heritage, New York-London 1991.

Brenner M., The Renaissance of Jewish Culture in Weimar Germany, New Haven 1996.

Derrida J., Archive Fever: A Freudian Impression, tłum. ang. E. Prenowitz, Chicago 1996.

Derrida J., Dissemination, tłum. B. Johnson, Chicago 1981.

Derrida J., Of Spirit: Heidegger and the Question, Chicago 1989.

Derrida J., Response to D. Libeskind, [w:] D. Libeskind, A.P.A. Belloli (red.), Daniel Libeskind, Radix-Matrix: Architecture and Writings, Munich-New York 1997, s. $110-115$.

Derrida J., Writing and Difference, Chicago 1978. Wyd. polskie: Pismo i różnica, tłum. K. Kłosiński, Warszawa 2004 (Tytuł oryginału: Lécriture et la différence - 1967).

Domańska E., „Niechaj umarli grzebią żywych”. Monumentalna przeciw-Historia Daniela Libeskinda, Teksty Drugie 1-2, 2004, s. 78-102.

Dorner E., Daniel Libeskind, Jüdisches Museum, Berlin 1999.

Eisen A., Galut: Modern Jewish Reflection on Homelessness and Homecoming, Bloomington 1986.

Ellin N. (red.), Architecture of Fear, New York 1995.

Freud S., Pisma psychologiczne, tłum. R. Reszke, Warszawa 1997.

Freud S., The Uncanny (Das Unheimliche), [w:] The Standard Edition of the Complete Psychological Works of Sigmund Freud, red. i tłum. J. Strachey, 17, London 1995, s. 217-256. 
Gay R., The Jews of Germany. A Historical Portrait, New Haven-London 1992.

Gidal N.T., Jews in Germany. From Roman Times to the Weimar Republic, Cologne 1998.

Gilman S., Love+Marriage=Death. And Other Essays on Representing Difference, Stanford, California 1998.

Gilman S., Smart Jews. The Construction of the Image of Jewish Superior Intelligence, Lincoln-London 1996.

Gilman S.L., Jews in Today's German Culture, Bloomington-Indianapolis 1995.

Heidegger M., What is a Thing?, tłum. W.B. Barton, V. Deutsch, Chicago 1967. Wyd. polskie: Pytanie o rzecz, tłum. J. Mizera, Warszawa 2001.

Huyssen A., Berlińskie Pustki, tłum. J. Mostowska, [w:] M. Saryusz-Wolska (red.), Pamięć zbiorowa i kulturowa. Współczesna perspektywa niemiecka, Kraków 2009, s. 432-457.

Huyssen A., The Voids of Berlin, Critical Inquiry 24, 1, 1997, s. 57-81.

Kockelmans J.J., A First Introduction to Husserl's Phenomenology, Pittsburg 1967.

Lenartowicz J.K., Architektura trwogi, [w:] T. Majewski, A. Zajdler-Janiszewska (red.), Pamięć Shoah. Kulturowe reprezentacje i praktyki upamiętnienia, Łódź 2009, s. 605-616.

Libeskind D., Between the Lines, [w:] K. Feireiss (red.), Daniel Libeskind: Erweiterung des Berlin Museums mit Abteilung Jüdisches Museum/Daniel Libeskind: Extension to the Berlin Museum with Jewish Museum Department (katalog niem./ang.), Berlin 1992, s. 57-59.

Libeskind D., Line of Fire, 1-3, Geneva-Milan 1988.

Libeskind D., Przełom: przygody w życiu i architekturze, tłum. M. Zawadka, Warszawa 2004.

Libeskind D., The Myth of Site, [w:] D. Libeskind, A.P. Belloli (red.), Daniel Libeskind, Radix-Matrix: Architecture and Writings, Munich-New York 1997, s. $140-142$.

Libeskind D., Trauma, [w:] S. Horstein, F. Jacobowitz (red.), Image and Remembrance. Representation and the Holocaust, Bloomington-Indianapolis 2003, s. $43-58$.

Lubiak J., O nowy kształt pamięci. Muzeum Żydowskie w Berlinie, [w:] T. Majewski, A. Zajdler-Janiszewska (red.), Pamięć Shoah. Kulturowe reprezentacje i praktyki upamiętnienia, Łódź 2009, s. 619-627.

Mirzoeff N., Inside/Out: Jewishness Imagines Emancipation, [w:] S. Tumarkin Goodman (red.) (kat. wyst.), The Emergence of Jewish Artists in NineteethCentury Europe, The Jewish Museum New York, New York 2002, s. 40-47. 
Morris L., Zipes J. (red.), Unlikely History. The Changing German-Jewish Symbiosis, 1945-2000, New York 2002.

Mumford L., The Culture of the Cities, New York 1938.

Musil R., Posthumous Papers of a Living Author, tłum. P. Wortsman, Hygiene, CO, 1987.

Nietzsche F., Pożyteczność i szkodliwość historyi dla życia, tłum. L. Staff, [w:] Dzieła Nietzschego, XIII, Warszawa 1912, s. 110-116.

Nora P., Between Memory and History: Les Lieux de Memoire, tłum. M. Roudebish, Representations 13, 1989.

Peck J.M., Being Jewish in the New Germany, New Brunswick 2006.

Pöggeler O., Martin Heidegger’s Path of Thinking, tłum. D. Magurshak, S. Barber, New Haven 1987.

Popczyk M., Przestrzenie pamięci: żydowskie muzea Daniela Libeskinda, [w:] T. Majewski, A. Zajdler-Janiszewska (red.), Pamięć Shoah. Kulturowe reprezentacje i praktyki upamiętnienia, Łódź 2009, s. 629-636.

Readings B. (red.), Vision and Textuality, Durham 1995, s. 115-140.

Rewers E., Doświadczenie pamięci, doświadczenie pustki, [w:] T. Majewski, A. Zajdler-Janiszewska (red.), Pamięć Shoah. Kulturowe reprezentacje i praktyki upamiętnienia, Łódź 2009, s. 595-603.

Ricoeur P., Husserl: An Analysis of His Phenomenology, Evanston 1967.

Rogoff I., The Aesthetics of Post-History: A German Perspective, [w:] S. Melville, R. Safranski, Martin Heidegger: Between Good and Evil, Cambridge, Mass. 1998.

Saryusz-Wolska M. (red.), Pamięć zbiorowa i kulturowa. Współczesna perspektywa niemiecka, Kraków 2009 („Wprowadzenie” tejże, s. 7-38).

Schneider B., Daniel Libeskind: Jewish Museum of Berlin. Between the Lines, Munich 1999 (wyd. 4, Daniel Libeskind: Jewish Museum Berlin, Munch 2005).

Stories of an Exhibition. Two Millenia of German Jewish History (autor zbiorowy, wprowadzenie: Julian Nida-Rümelin), Stiftung Jüdisches Museum Berlin 2005.

Straeten B. van der, The Uncanny and the Architecture of Deconstruction, red. A. Masschelein, Image \& Narrative - Online Magazine of the Visual Narrative, Daniel Libeskind (dostęp: 12.11.2013).

Taylor M.C., Point of No Return, [w:] D. Libeskind, A.P. Belloli (red.), Daniel Libeskind. Radix-Matrix: Architecture and Writings, Munich-New York 1997, s. 128-135.

Vidler A., The architectural uncanny: Essays in the Modern Unhomely, Cambridge, Mass 1992. 
Vidler A., Warped Space. Art, Architecture, and Anxiety in Modern Culture. Cambridge, Mass. 2000.

Volkov S., Pomysł na nowoczesność. Żydzi niemieccy w XIX i na początku XX wieku, tłum. J. Górny, P. Pieńkowska, Warszawa 2006.

Wąs C., Zagadnienia interpretacji architektury w filozofii Jacquesa Derridy, [w:] B. Małczyński, R. Włodarczyk (red.), Czytanie Derridy, Wrocław 2005, s. $41-47$.

Wettstein H. (red.), Diaspora \& Exiles. Varieties of Jewish Identity, London 2002. Wigley W., The Domestification of the House: Deconstruction after Architecture, [w:] P. Brunette, D. Wills (red.), Deconstruction and the Visual Arts. Art, Media, Architecture, Cambridge University Press 1994, s. 203-227.

Wigley M., The Architecture of Deconstruction: Derrida's Haunt, Cambridge 1993, tłumaczenie: M. Pawlikowska, U-domowienie domu: Dekonstrukcja po architekturze, [w:] B. Małczyński, R. Włodarczyk (red.), Czytanie Derridy, Wrocław 2005, s. 93-108.

Wigoder G., Słownik biograficzny Żydów, tłum. A. Jaraczewski, I. Kałużyńska, P. Łomnicki, A.M. Nowak, B. Stokłosa, Warszawa 1998.

Winzen M., The Need for Public Representation and the Burden of German Past, Art Journal 309, 1989.

Wistrich R.S., Between Redemption and Perdition. Modern Antisemitism and Jewish identity, London 1990 (rozdz. 6: The Jewishness of Sigmund Freud), s. 71-85.

Wistrich R.S., Xenophobia and Antisemitism in the New Europe: The Case of Germany, [w:] idem (red.), Demonizing the Other. Antisemitism, Racism and Xenophobia, Jerusalem 1999, s. 349-363.

Wood N., The Victim's Resentments, [w:] B. Cheyette, L. Marcus (red.), Modernity, Culture and 'the Jew, s. 257-267.

www.imageandnarrative.be/inarchive/uncanny/bartvanderstraeten.htm (dostęp: 12.11.2013).

Young J.E., At Memory's Edge. After-Image of the Holocaust in Contemporary Art and Architecture, New Haven-London 2000.

Young J.E., Daniel Libeskind's New Jewish Architecture, [w:] C. Wolf (red.), Daniel Libeskind and the Contemporary Jewish Museum: New Jewish Architecture from Berlin to San Francisco, San Francisco 2008, s. 45-61.

Young J.E., Memory and Counter-Memory: Towards a Social Aesthetic of Holocaust Memorials, [w:] M. Bohm-Duchen (red.), After Auschwitz: Responses to the Holocaust in Contemporary Art, London 1995, s. 78-102.

Young J.E., Pamięć i kontrpamięć. W poszukiwaniu społecznej estetyki pomników Holokaustu, tłum. G. Dąbkowski, Literatura na Świecie 1-2, 2004, s. 267-289. 
Tekst jest tłumaczeniem fragmentu książki J.E. Younga pt.: The Texture of Memory: Holocaust Memorials and Meaning, New Haven 1993, s. 17-48.

Young J.E., The Arts of Jewish Memory in a Postmodern Age, [w:] B. Chayette, L. Marcus (red.), Modernity, Culture and the Jew, Cambridge 1998, s. 211-225. Young J.E., The Counter-monument: Memory Against Itself in Germany Today, Critical Inquiry 267, 1992. 
